\title{
ARTICLE
}

\section{Using restorative justice to rethink the temporality of transition in Chile}

\author{
Marit de Haan and Tine Destrooper ${ }^{*}$
}

\begin{abstract}
Assumptions of linear progress and a clean break with the past have long characterised transitional justice interventions. This notion of temporality has increasingly been problematised in transitional justice scholarship and practice. Scholars have argued that a more complex understanding of temporalities is needed that better accommodates the temporal messiness and complexity of transitions, including their ongoingness, multilayeredness and multidirectionality. Existing critiques, however, have not yet resulted in a new conceptual framework for thinking about transitional temporalities. This article builds on insights from the field of restorative justice to develop such a framework. This framework foregrounds longer timelines, multilayered temporalities and temporal ecologies to better reflect reality on the ground and victims' lived experiences. We argue that restorative justice is a useful starting point to develop such a temporal framework because of its actor-oriented, flexible and interactive nature and proximity to the field of transitional justice. Throughout this article we use the case of Chile to illustrate some of the complex temporal dynamics of transition and to illustrate what a more context-sensitive temporal lens could mean for such cases of unfinished transition.
\end{abstract}

Keywords: temporality, transitional justice, restorative justice, Chile, ongoingness, multilayeredness \& multidirectionality.

\section{Introduction}

The premise that the past bears upon the present lies at the heart of transitional justice scholarship and practice. Yet, historically, scholars and practitioners of transitional justice have paid markedly little attention to how it does so. This can be traced back to the fact that the field has long been characterised by a rather simplified understanding of time and temporality, rooted in an assumption of a

* Marit de Haan is a PhD researcher at the Human Rights Centre of Ghent University, Belgium. Tine Destrooper is Associate Professor of Transitional Justice at the Human Rights Centre of Ghent University, Belgium.

Contact author: marit.dehaan@ugent.be. 
clean break with the past and linear progress towards a preconceived ideal. In the past decade, however, the acknowledgment that transitions 'happen in bouts or waves' (Roht-Arriaza \& Mariezcurrena, 2006) sparked a rich scholarly debate about these temporal assumptions (Mueller-Hirth, 2016; Obel Hansen, 2017; Turner, 2017). This debate problematised some taken-for-granted temporal assumptions of transitional justice and the unforeseen consequences thereof. So far, however, these critiques have not resulted in a structured reconceptualisation of transitional temporalities.

In this article, we seek to move beyond these critiques and propose a new temporal framework for transitional justice rooted in restorative justice. Our proposed framework constructs temporalities on the basis of lived experiences and understandings of duration that are indeterminate and plural (cfr. Kairos) (see Crawford, 2015; Hinton, 2018). Such a framework better reflects and interacts with the lived and complex realities of those who suffered (past or ongoing) violence and injustice than a temporal framework that follows chronological or 'calendar' time (cfr. Chronos), which often underlies transitional justice practice. ${ }^{1}$

The importance of a more adequate temporal framework rooted in rightsholders' lived realities becomes clear when we consider that even some of the most paradigmatic cases of 'finished' transitions today raise questions about how 'finished' those transitions really are. Chile is one such case that has been widely considered a successful transition from an authoritarian regime (1973-1990) to a democracy and that initiated a paradigmatic transitional justice process in 1990. The process followed a classical linear sequencing: the most serious human rights violations were addressed first in truth and reparations programmes, while other kinds of violations were to be dealt with later. ${ }^{2}$ However, Chile's past is penetrating the present in ways that suggest that the transition is far from 'finished': truth and reconciliation were hampered due to pacts of silence among former state actors; justice efforts had a limited reach due to amnesty legislation that remained in force until 2006; clear institutional reform has largely been absent as the deliberately scripted transition left many aspects of the military regime in place; ${ }^{3}$ and, most importantly, victims have often been left waiting, while social and economic injustices are ongoing (Collins, 2013; Ferrara, 2015). Several authors have therefore started to refer to the Chilean case as an 'unfinished struggle for truth and justice' (Borzutzky, 2017; Ferrara, 2015: 200). This unfinished struggle, in October 2019, transformed into outright protest

1 We use the notion of temporality to refer to something that exists within or that has some relationship with time. We use the notion of time to refer to linear progressive calendar time.

2 The first truth commission (Comisión Nacional de Verdad y Reconciliación, hereafter 'Rettig Commission') in 1991 focused on disappearance, execution and torture resulting in death. Only in 2004 was there attention to those who survived violations, when the Comisión Nacional sobre Prisión Política y Tortura (hereafter 'Valech Commission') addressed torture and political detention. An extensive reparation system was rolled out, and, more recently, justice efforts are increasing.

3 Pinochet continued as head of the military until 1997, was later granted the status of senator for life, and the military remained 'undefeated and unreformed' (Collins, 2013; McAuliffe, 2014). 
when people took to the streets. These protests, which eventually led to the referendum on constitutional reform in October 2020, were no 'sudden awakening' but reflected a struggle with deeper historical roots (Moyano, 2019). As such, they offer an interesting entry point to scrutinise the temporal dynamics that link various experiences of injustice.

This article first discusses some of the temporal complexities of transitional justice. It then reflects on how restorative justice principles could be useful in addressing these and subsequently develops a conceptual framework for thinking about transitional temporalities on the basis of that discussion. Throughout, the case of Chile is used to illustrate the added value of such a temporal framework and to advance, open up and concretise a wider conceptual argument. As such, the article is not an in-depth study of the Chilean case. Nor is it a blueprint for practitioners or an uncritical plea for restorative justice: some of the critiques raised about transitional justice also apply to restorative justice, and in practice macro-politics (seldom free of underlying and contrasting interests) can override even the loftiest principles. This, however, should not keep us from engaging in conceptual exercises aimed at improving the existing paradigms that guide our thinking and action. Engaging in this exercise, we argue, is a precondition for envisioning more holistic justice processes that are more in line with victims' experiences.

\section{The temporal complexity of transitional justice}

Transitional justice as a field of scholarship and practice is concerned with questions related to the legacy of large-scale violence. It has been decisively shaped by legal practitioners who made normative links between transitional justice processes - for example, criminal trials, truth commissions or reparations - and broader societal and systemic outcomes, such as healing, reconciliation and peace (Macdonald, 2015). Despite its popularity and expansion (or may be because of it) many practical and conceptual challenges have plagued this relatively young but rapidly expanding (non-)field (Bell, 2009; Madlingozi, 2010; Miller, 2008; Nickson \& Braithwaite, 2013).

Understanding temporality is one of those challenges (Zunino, 2019). Despite excellent problematisations of transitional justice's temporal assumptions, many interventions in practice continue to be - implicitly or explicitly - rooted in the assumption that events have 'an overall beginning, middle and end, in which injustice and violence are replaced with law and ultimately peace and justice' (Turner, 2017: 70). This interpretation has the effect of

fitting the conflict into a neat linear account of historical factors that caused the conflict, and that can then be isolated as a means of addressing that conflict and preventing its recurrence (Ibid.: 70). 
This, in turn, requires 'the possibility of a unified and progressive narrative in which the past can be separated from the present, and indeed from the future' (Ibid.). Yet transitional justice operates in contexts that have a great degree of temporal complexity, notably because past, present and future are all infused with interrelated normative claims (McLeod, Dimitrijevic \& Rakocevic, 2013). Even if recent scholarship increasingly recognises transitions as more continuous, the working hypothesis has long been one of rupture, of an identifiable and timedelimited moment when change happens. ${ }^{4}$ This 'dramatically compressed' understanding of time (Bell, 2009) can also be understood in light of transitional justice's ambition to 'urgently shape and sanitise the public sphere' (Demiragic \& Hodzic, 2013: 149). ${ }^{5}$

In the remainder of this section we discuss five ways in which these temporal assumptions can impose an inadequate temporal mould onto complex situations, which risks invisibilising lived experiences that are crucial for victims. We interlace this discussion with illustrative examples from the Chilean case.

\subsection{Contained temporal mandates vs. structural violence and injustice}

Transitional justice interventions' contained temporal mandate means that only violations committed during a certain period can be examined. This often makes it impossible to consider the longue durée and ongoing nature of structural violence and structural injustice. Yet many instances of direct violence are - to a greater or lesser extent - related to dynamics of indirect structural, cultural or socio-economic violence, which has historical roots reaching far beyond what most transitional justice interventions consider (Galtung, 1969). ${ }^{6}$ Contained temporal mandates that ignore structural violence and injustice, thus, do not only challenge a transformative outcome of the transitional justice process ${ }^{7}$ but also invisibilise the extent to which the past continues into the present. The effects of structural violence tend to be continuous pre-, trans- and post-conflict and can themselves fuel new waves of conflict (Edkins, 2003; Lambourne \& Niyonzima, 2016; Raehme, 2018).

In the Chilean context, Macarena Gómez-Barris (2015: 75) identifies the experiences of Mapuche indigenous people in the Southern Cone, as well as

4 We subscribe to the critique of rupture on a societal level, while recognising that on an individual level certain events in an individual's life are likely to be experienced as rupture, whether this is an experience of violence or, on the contrary, of receiving a reparation.

5 This preference for discrete intervals continues to characterise many transitional justice processes today, most notably criminal justice proceedings or commissions of inquiry. At the same time, there has also been a move towards more open-ended approaches. The Tunisian, Ecuadorian and Peruvian truth commissions, for example, have had temporally wide mandates, with some going as far back as decolonisation struggles in one direction and ongoing disputes in the other (Andrieu, 2016; Hayner, 2011).

6 Structural violence refers to violence that is built into societal structures and that results in unequal power, unequal life chances and social injustice. Cultural violence refers to the cultural practices that facilitate this kind of violence (Galtung, 1990).

7 While not all transitional justice interventions have a transformative aim, the paradigm of transformative justice has quickly gained prominence in the field of transitional justice (Gready \& Robins, 2014; Ketelaars, 2018). 
widespread and persistent inequality among the general population as examples of entrenched and ongoing structural violence and injustice that were relatively unaffected by both the Chilean dictatorship and the 'transitional moment'. These structural injustices and persisting inequalities were present pre-, trans- and post-authoritarianism. The relevance of this structural injustice and inequality for the present day became clear when large-scale protests erupted in October 2019. After the price of metro tickets increased by 30 pesos (around $€$ 0,03), 1.2 million people participated in marches, chanting 'it's not 30 pesos, it's 30 years'. This made clear that these protests were not so much about the actual price of public transport as much as they were about ongoing social and economic inequality. Cristina Moyano calls this an illustration of a past that 'does not pass' (2019: 12). Indeed, the protests reflect the longue durée and ongoing nature of structural inequality and injustice and the extent to which these issues have been insufficiently dealt with during the transitional justice process. A recent report showed that in Chile, as in many other paradigmatic transitional justice cases, structural injustice, inequality and the violation of economic, social and cultural rights $(\mathrm{ESCR})^{8}$ have been largely neglected. ESCR violations, for example, stayed mostly under the radar or were dealt with as mere contextual factors or collateral consequences (UDP, 2019: 34, also see Schmid, 2015). These inequalities have been inspiring protests within different social groups from 2006 onwards (AsteLeiva, 2020).

\subsection{Moving fast vs. moving at various paces}

The inability to consider structural violence and injustice is not only related to the contained temporal mandates, but also to the fixed end point of most transitional justice interventions. When faced with a complex reality, transitional justice practitioners, political leaders and donors alike tend to prefer institutionalised 'closure', over possible protracted or truncated processes. Truth commissions are usually expected to present their reports after a few years (at most), and reparation programmes are usually rolled out in the few years following transition (after which there is often no more financing for more structural forms of reparations or reparations for structural violence). If the violence and injustice that should be considered are of an enduring and structural nature, interventions with short timelines are likely inappropriate. They risk overlooking entrenched injustice and violence and might, moreover, exclude those not ready or willing to come forward at the time of intervention.

This can also be observed in the case of the two Chilean truth commissions. While these covered the full period of the dictatorship (1973-1990), they were commissioned to deliver their reports within six months from their establishment, with a potential extension of three more months. ${ }^{9}$ This led both

8 Including, among other things, access to education, health and social security; censorship of cultural expression; and forced evictions (UDP, 2019).

9 Decretos Supremos $\mathrm{N}^{\circ} 355$ and $\mathrm{N}^{\circ} 1.040$ (https://pdh.minjusticia.gob.cl/wp-content/uploads/ 2015/12/Creacion-Comision-Rettig.pdf) （www.indh.cl/wp-content/uploads/2010/10/ds1040. pdf). 
commissions to focus on the most obvious and visible kinds of violence and injustice and to propose reparations and reform measures that could be implemented relatively easily and quickly, rather than considering more indirect forms of harm or having a long-term vision that would give victims a chance to step forward when they are ready to do so. That the end point of these commissions' work did not coincide with the end point of victims' own quest for truth and justice is exemplified by victims' weekly engagement in protests around the presidential palace, using slogans like '¡Justicia, Verdad, no a la impunidad!' ('justice, truth, no to impunity!'), which continues until this day. These protests illustrate that transitional justice processes cannot be contained within brief temporal mandates but have an ongoing importance and happen in bouts and waves' (see above), often when a momentum is created that makes issues related to structural injustice resurface.

\subsection{The experience of victimisation}

The previous point underlines the extent to which ongoing (structural) violence results in ongoing victimisation. As Laurel Fletcher and Harvey Weinstein (2017: 171) demonstrate, as victims' needs, their sense of agency and their strategies for overcoming harm change over time, victims are likely to want different things from transitional justice interventions at various stages of the process. These changing needs and priorities are likely to be exacerbated in a context of ongoing victimisation. Moreover, ongoing victimisation increases the risk of compound or combined victimisation. Think, for example, of someone belonging to a historically marginalised group who experiences sexual violence, while being unlawfully detained and who faces social stigma on returning, which challenges their livelihood. These compound experiences of victimisation all impact on the present, each according to its own timeline. As such, both at an individual and at a societal level, timelines of (overcoming) harm intersect and coexist, and they rarely do so in predictable or linear ways. The multiple ways in which people recover agency in the face of ongoing and compound victimisation often contrast with the political and societal expectations to move on, which risks marginalising victims of compound or ongoing victimisation sociotemporally (Mueller-Hirth, 2016). Moreover, the complex and intersecting timelines that come with compound and ongoing victimisation affect victims' resilience and readiness to participate in the transitional justice process. The restricted time horizon of many transitional justice mechanisms results in excluding those who are not yet ready to deal with the past or who have not developed a sense of agency in the initial transitional justice period (Arthur, 2009; Clamp, 2019).

In Chile, ongoing and compound victimisation can be observed partly in the effects of the structural violence and injustice described previously. It can also, however, be observed within the transitional justice architecture itself. The focus and restricted (temporal) mandates of the transitional justice interventions meant that the experiences of many victims went unacknowledged, excluding them from access to remedy. This neglect of one's right to reparation and participation has likely intensified and aggravated the primary victimisation experiences, linking past and ongoing victimisation to the present. This lack of 
acknowledgment becomes clear from constant pressure from victim groups on transitional justice mechanisms, which led to the establishment of an additional truth commission in 2010 that focused on the (re)consideration of cases rejected or not presented in previous truth commissions (Ferrara, 2015) ${ }^{10}$ and a recent revival of victim-initiated justice processes (Collins, 2013). Anita Ferrara (2015: 190) explains how 'cultural and psychological barriers of fear' prevented victims from stepping forward during earlier stages of the transitional justice process.

\subsection{Transitional history and multidirectional memory}

A focus on history and memory further challenges transitional justice's temporal assumptions. There is no uncontested history out there, 'behind us', for us to dig up (Ignatieff, 1996). Yet, in practice, transitional justice initiatives that seek to bring to the surface 'the truth' about 'the past' often utilise a rationality suggesting that dealing with 'the past' will enable the achievement of a positive future that is deemed morally acceptable. This is, for example, visible in the logic of 'nunca mas' reports (Hayner, 2011) and the recent boom in memorial museums and memorialisation initiatives (Huyssen, 2000; Sodaro, 2018). Teresa Oteíza and Claudio Pineur (2010) have demonstrated how the reports of the Chilean truth commissions also distinguish very clearly between past, present and future, while, in fact, the dynamics of memory cannot be understood in such a linear way. The fact that not one but several truth commissions, and later reconsideration efforts, were needed further illustrates that memories about the past are not easily captured in one instance of time.

This relates to the more fundamental concern that memory itself is not a linearly structured archive for us to tap into. ${ }^{11}$ Memory reincarnates, resurrects, recycles and refuses to keep the past in the past, and often disrupts historical chronology, resignifying events of the pasts in light of an ever-changing present (Oteíza \& Pineur, 2010; Spiegel, 2002). Referring to memory as 'the present past' (Terdiman, 1993: 8), the 'eternal present' (Nora, 1989) or 'eternal contemporaneity’ (Yerushalmi, 2002: 96) underlines memory’s embeddedness in a - radically - different temporal structure than history, i.e. one that requires a more cyclical, multidimensional and iterative understanding of temporality. In the Chilean context, for example, one victim testified how the government's repressive reaction to the protest of 2019 resurfaced (traumatic) memories among victims, illustrating the extent to which traumatic memories of the past

10 The Comisión Asesora para la Calificación de Detenidos Desaparecidos, Ejecutados y Víctimas de Prisión Politica y la Tortura (2010) examined cases that had not been presented before or that were rejected in previous truth commissions. Around 32,000 cases were presented for reconsideration, leading to the additional recognition of 9,795 cases of torture and political detention and 30 cases of disappearance and political execution (Ferrara, 2015) (Decreto Supremo, no. 43, Ministerio del Interior, 5 February 2010).

11 This absence of a linear chronological order, the inability to distinguish between past and present, and the interwovenness of 'facts' and emotional and personal experiences are also characteristic of traumatic memory. This defies the straightforward linear narrative of healing and recovery of agency that underlies many transitional justice interventions (Caruth, 1996; LaCapra, 2001; Laub, 1995). 
shape the present and future. ${ }^{12}$ Alejandro Castillejo-Cuéllar (2014: 59) describes testimonies in the context of transitional justice as 'complex textures that wove time and space in a fashion that was not necessarily linear'. This freely moving nature of memories, he argues, defies streamlined protocols, structures and categorisations. Transitional justice processes must therefore consider the complex temporal structures that characterise the operation of memory.

\subsection{Vernacular understandings of time and temporality}

While the previous critiques of transitional justice's temporal working hypothesis relate to the specific context of transition, it should also be noted that transitional justice interventions are usually rolled out in very diverse places, where vernacular or localised understandings of time and temporality may a priori be different. Alexander Hinton (2018: 202) conceptualises vernacular time as 'the specific local understandings and temporal practices operative in a given locality'. This could refer to a vernacular understanding that sees both being and time as cyclical rather than linear. These vernacular temporalities provide orientations to the world, analyse and deconstruct time and provide maps for lived experience, including emotions (Hinton, 2018: 187). They are shaped within lived realities that involve a great variety, subjectivity and complexity (Hickey \& Mohan, 2004). They represent certain kinds of experiences that seem to be layered and situated simultaneously in multiple spaces and temporalities that question and look differently upon the relationship between past, present and future.

As Marije Hristova, Fransisco Ferrándiz and Johanna Vollmeyer (2020: 786) argue, foregrounding these vernacular understandings of time and temporality can shed light on potential dissonances and frictions between human rights or transitional justice operatives and local forms and institutions of time and memory related to social suffering and healing. These dissonances, frictions and disruptions, moreover, show the necessity of thinking about alternative ways to conceptualise temporality in transitional justice in ways that reflect and accommodate this complexity. It is therefore important to move away from the one-size-fits-all temporal model and to question its unintended effects on local populations. Indeed, different temporalities are shaped by the interplay between the epistemologies, social spaces and historical contexts in which they emerge. Staying within one temporal framework can entail the invisibilisation of others that do not fit the parameters of legibility (Vazquez, 2011).

In the Chilean case, these vernacular temporalities have likely been overlooked in the concrete sequencing of early truth and reparation efforts and later focus on justice (Collins, 2013). This division of Chile's transitional justice period into concrete sequences holds assumptions that do not necessarily reflect victims' complex temporalities.

12 This was indicated by a victim of various human rights violations during the dictatorship in personal communication with the first author in October 2019. 


\section{Restorative justice as a temporally sensitive field?}

In the foregoing we applied the most relevant temporal critiques of transitional justice to the Chilean case to illustrate how they render certain dynamics invisible. Indeed, even in a paradigmatic case like Chile, the transition might not be as 'finished' as generally assumed, and more complex temporal dynamics are at play. We need a more suitable conceptual framework that can account for the temporal complexity of transitional justice contexts. In this article, we argue that the principles underlying restorative justice can inspire such a framework for various reasons. In this section we zoom in on those principles.

We understand restorative justice as a series of practices and discourses focused on repairing the harm caused by criminal behaviour through the participation of all affected parties in the resolution of conflict (Braithwaite, 2003; McEvoy \& Eriksson, 2006). Whereas criminal justice - which underlines much of transitional justice practice - sees crime as a breach of the law, restorative justice focuses on the harm done to interpersonal relationships, the needs that emerge for the victim, the obligation(s) for the offender to repair the harm and the added value of dialogue (e.g. De Keijser, 2000: 29; McEvoy \& Eriksson, 2006; Weitekamp, Vanspauwen, Parmentier, Valiñas \& Gerits, 2006; Zehr, 2002). Over the last decade, process-based and actor-oriented approaches (Marshall, 1996: 6; Morris, 2002) have gained prominence over outcome-based approaches to restorative justice (e.g. Bazemore \& Walgrave, 1999; Walgrave, 2008) (Clamp \& Doak, 2012), which allows for a more profound engagement with lived realities and vernacular temporalities. Because these principles resonate strongly with the needs of political transitions (Leebaw, 2001; Minow, 1998; Teitel, 2000), certain principles of restorative justice have become increasingly popular in the domain of transitional justice, which has borrowed from it in several ways (Eriksson, 2009; Weitekamp et al., 2006). ${ }^{13}$

\section{How restorative justice inspired transitional justice}

Elements and principles of restorative justice have inspired transitional justice interventions in several ways (e.g. Clamp, 2019; Clamp \& Doak, 2012; Daly, 2015; McEvoy \& Eriksson, 2006; O’Mahony, Doak \& Clamp, 2012; Weitekamp et al., 2006). Elmar Weitekamp et al. (2006) explain this conceptual borrowing by underlining the perceived shortcomings of transitional justice's original focus on retributive justice mechanisms. Kerry Clamp and Jonathan Doak (2012) underline that, in parallel, within the domain of restorative justice there has been growing concern with responding to collective and societal harm, making it more relevant in transitional justice contexts. ${ }^{14}$

13 This discussion of restorative justice principles is not to brush over the fact that, in practice as well as in theory, restorative justice, like transitional justice, has been plagued by its own practical and conceptual challenges and struggles. For a critical reflection, see, for example, Kathleen Daly (2006).

14 In spite of similarities and overlaps, Kerry Clamp and Jonathan Doak (2012: 354) also identified fundamental differences, mostly centred on the private versus public debate. 
In each of the four pillars of transitional justice, ${ }^{15}$ scholars and practitioners have been quoting restorative justice values and principles to develop and defend their approach. This has been most obvious with regard to truth commissions. The South African Truth and Reconciliation Commission, for example, illustrates how truth-telling has been assumed to - inherently - have a reconciling potential, particularly because it sought to bring together all the affected parties and their communities. ${ }^{16}$ Yet few scholars or practitioners today would argue that truthtelling has a restorative and reconciliatory nature per se, if not systematically embedded in the appropriate framework. In Chile, for example, the two truth commissions focused on collecting victims' testimonies and mapping numbers of victims but did not include perpetrators, had no community-based approach and did not tailor reparations to victims' preferences. These elements would be required if this were a truly restorative approach. Also in (criminal) justice proceedings, references to restorative justice have become increasingly frequent. These references, however, sit uncomfortably with the top-down implementation of most (criminal) justice proceedings, which raises questions about, for example, the risk of instrumentalising victims (Lin, 2005). The same is true for many reparation programmes and programmes under the transitional justice pillar of guarantees of non-recurrence that have been looking at restorative justice principles, e.g. when advocating for symbolic or community-based forms of reparations and memorialisation but without necessarily using the constitutive logic of restorative justice as an organising principle (McEvoy \& Eriksson, 2006).

In addition to these various practical kinds of borrowing from restorative justice, transitional justice's paradigm shift towards more bottom-up, victimcentred, community-based and participatory approaches has been argued to show similarities to restorative justice principles of engaging those most affected in the justice process (Aldana, 2006; Frederiksen, 2008; O'Connell, 2005; Robins, 2011). Ray Nickson and John Braithwaite's suggestion (2013) that transitional justice processes should broaden (i.e. integrate different perspectives on justice, such as procedural, retributive and distributive justice), deepen (i.e. become more actorcentred) and become longer (i.e. step away from the idea of malleability and allow for initiatives that are not time constrained) is also in line with restorative justice's principles.

While the label 'restorative justice' implicitly invokes the possibility to return to a previous state (which might be undesirable and virtually impossible in the context of victimisation), scholars have stressed its future orientation through the prevention of future harm (Crawford, 2015: 475; Shapland et al., 2006: 516). We do not see restorative justice as a panacea for all the most pressing challenges of transitional justice but acknowledge the rhetorical and conceptual borrowing that is already taking place and explore whether the debate on temporality in

15 The four pillars of transitional justice are generally understood as truth, justice, reparation and guarantees of non-recurrence.

16 Kathleen Daly (2015) warns that references to the restorative potential of truth-telling should not too easily be understood as an appreciation of restorative justice principles, since the growing popularity of truth commissions can also be understood in reference to the increased difficulty of pursuing criminal accountability. 
transitional justice can also be assessed from that perspective. In this domain conceptual borrowing has been limited (for an exception, see Crawford, 2015). ${ }^{17}$ We seek to close this gap by proposing a new conceptual framework for transitional temporalities that is inspired by the principles - if not always the practice - of restorative justice.

\section{A new conceptual framework for transitional temporalities}

In this section we build on three principles underlying restorative justice to construct a conceptual framework for thinking about temporality in transitional contexts. We acknowledge that these principles are ideal types and that, in practice, even restorative justice interventions themselves do not or cannot always fully abide by them and may be overridden by micro- or macro-politics. ${ }^{18}$ Like transitional justice, restorative justice interventions, too, face many restrictions on the ground. This, however, does not make these principles any less interesting from a theoretical point of view, as they reflect the core values and conceptual logic of restorative justice. The framework we construct on the basis of these principles is a proposal to move beyond the critiques of transitional justice's temporality in a constructive manner and to develop a temporal conceptual framework that starts from an acknowledgment of complexity (Homer-Dixon, 2011) and messiness (Goodale, 2006; Nowotny, 2017) rather than obscuring them.

\subsection{Ongoingness}

The first principle of restorative justice that inspires our conceptual framework for thinking about temporality in transitional justice is its temporal openendedness, i.e. its openness to both start and end a process at various points in time. We refer to this characteristic using the notion of 'ongoingness' to underline the incompleteness, open-endedness and unfinished quality of the processes of victimisation and structural injustice, as well as those of justiceseeking efforts. The notion of ongoingness also allows us to move beyond temporal paradigms centred on notions of 'rupture' or discrete and contained 'transitional moments' (also see Obel Hansen, 2017). It is still rooted in a rather linear way of thinking, which we complement with more multilayered and multidirectional temporal perspectives in the next two sections. Transitional justice's 'dramatically compressed' understanding of time (Bell, 2009) has resulted in a preference for undertaking interventions as soon after the tragic event as possible, promoting closure and speedy trials. In Chile, this is reflected, for example, in the requirement that the truth commissions deliver their reports within a few months after their establishment. While this preference for starting

17 Indeed, Adam Crawford (2015: 72) criticises the extent to which restorative justice is itself currently theorised as a 'free-floating concept untouched by time or temporality' and argues that it should pay more attention to how past, present and future are intertwined.

18 In some contexts, restorative justice has been applied as a 'quick solution' to long waiting times in the criminal justice system, or limits have been set to the number of encounters. 
the transitional justice process early on is justified - and indeed needed - to send a prompt signal about justice and accountability, closing transitional justice institutions soon after they were established might be more problematic, as this means that victims only have a limited time frame to come forward. Some victims might not be ready to do this when, for example, (fear of) violence is ongoing. As Kerry Clamp (2019) argues, some individuals might not be ready to deal with the past at the time transitional justice mechanisms are implemented and on that account might be excluded from the broader transitional justice process. Moreover, time affects experiences and perceptions of justice. This is particularly important for victims who have historically been underprivileged and for whom ongoing injustices may interfere with their agency at different times in the process. Longer timelines, then, accommodate the need of those victims wishing to step forward at once, as well as the evolving needs and capacities of those who do not have agency or access early on. ${ }^{19}$ Longer timelines also accommodate the fact that new information often continues to surface, also after truth commissions have closed their doors or after verdicts have been obtained. This also means that even if a pause button is activated at some point, the process can resume later on, when momentum for those initiatives picks up again.

Thus, while it is crucial that victims are not kept waiting and that processes start early on, it is also insightful, and necessary, to consider how restorative justice's focus on process could meet the need for both immediate action and longer availability, how it could, in other words, redirect our focus towards the ongoingness of justice processes. Restorative justice principles do not privilege a delimited time frame but acknowledge that processes can be protracted and do not require predetermined beginnings or end points. This has been referred to as 'architectures of permanence' (Braithwaite, 2016; Nickson \& Braithwaite, 2013). Adam Crawford (2015: 484) adds that such an approach 'offers the potential to break free from the narrow time-frame of criminal justice'. A restorative justiceinspired temporal framework for transitional justice would thus accept the existence of protracted timelines and needs requiring remedy at various points in time.

In the Chilean case, the Museum of Memory and Human Rights in Santiago, established in 2010, resembles such an 'architecture of permanence' (Nickson \& Braithwaite, 2013). Besides providing a site for memorialisation and education, the documentation centre of the museum has an extensive oral archive in which victims of the dictatorship can leave their testimony on a continuous base. This means that they can step forward to testify and to engage with the transitional justice process when they are ready to do so, unlike the case with the two truth commissions. At the same time, despite this temporal openness in terms of when victims can come forward, the period considered is still relatively limited, covering only the period of military rule. This may lead to the invisibilisation of more deeply entrenched forms of violence.

The museum thus opens up the time frames for truth-telling and testimony in ways that go beyond the mandate of the truth commissions, but it is still 
unable to fully represent the more complex temporal dynamics of structural violence. In order to be fully considerate of the longue durée and structural nature of violence, such initiatives should not limit themselves to the violations that occurred within the specific time frame of dictatorship, but would benefit from a more encompassing understanding of issues such as structural inequality, social injustice and the violation of ESCR, which have deeper historical roots. So-called architectures of permanence should therefore be complemented with a broader temporal mandate that seeks to actively account for the longue durée and ongoing nature of structural violence and victimisation. Along these lines, the Chilean government presented a plan to create a permanent qualification committee in $2017^{20}$ that would increase availability and access by allowing victims to engage with it at their own preferred timing. However, to date this has not materialised (UDP, 2019).

Our first proposal, rooted in restorative justice, is therefore for transitional justice to acknowledge the ongoing nature of various kinds of violence and victimisation, the existence of protracted timelines for remedy and the need to think of interventions in terms of 'architectures of permanence'. We capture these various longer and open-ended temporalities under the notion of ongoingness. The Chilean example shows that this could take the form of mechanisms remaining available for a longer time, or even permanently or in an evolving format, so as to better accommodate victims' (evolving) justice needs and lived experience. It should be noted that allowing for flexible starting points and longer timelines is not an argument for postponing interventions but rather for ensuring that victims can engage with transitional justice mechanisms at a time that suits them. A focus on ongoingness is, however, insufficient to understand or address the complexity of transitional temporalities, because it still presumes the existence of a single timeline of linear progress. We therefore complement this focus on ongoingness with a second element rooted in restorative justice principles.

\subsection{Multilayeredness}

A second dimension of a more context-sensitive temporal framework for transitional justice is the recognition of coexisting, diverse and overlapping timelines, which should be understood within its unique context (Adam, 2008: 1). ${ }^{21}$ The compound and ongoing nature of harm, as well as the highly subjective way in which harm is experienced, means that individuals cope in very different ways with its effects and that recovering agency may happen at various paces. Within one individual the temporality of coping with various kinds of harm may be different, but between individuals too it may differ (Crawford, 2015; Rebolledo \& Rondón, 2010; Robins, 2017). As such, various timelines of harm, needs and

20 The proposal was to 'Promote the creation of a Permanent Qualification Commission to clarify all human rights violations committed during the dictatorship (political execution, forced disappearance and torture).' (Subsecretaría de Derechos Humanos, 2017: 24, own translation).

21 Barbara Adam introduces the notion of timescape to refer to time as composed of several temporal elements, or a 'cluster of temporal features', including a spatial and material notion (Adam, 2004: 143). 
recovering agency coexist, both at a societal level and within one person or group. These overlapping or multilayered timelines of (overcoming) harm, moreover, are often much more variable than the temporality envisioned by transitional justice interventions that engage, for example, with institutional reform.

The Chilean case is illustrative of these overlapping timelines and multilayered temporalities and of the formal transitional justice process' inability to capture this complexity of victims' experiences of structural and ongoing violence. The formal process adopted a sequencing logic that, rather than accepting the concurrent existence of multiple timelines, has assumed that certain issues can be closed before moving on to the next issue. The assumption, for example, that the most serious human rights violations should be dealt with first is reflected in the focus of the truth commission, whereby the first one ('Rettig' Commission, 1991) dealt only with disappearance and executions and the second only with torture and political detention ('Valech' Commission, 2004). After the Rettig Commission, attention to issues related to disappearances and executions decreased sharply in the formal transitional justice process, meaning that victims had limited access to remedy. Underlying this approach is the assumption that victims' experiences of harm can be mapped onto a predetermined unified time frame. If we accept, however, that victimisation affects individuals in different ways, different pathways and temporalities for action and restoring harm should reflect these lived realities. The way in which these two truth commissions have been organised means that only those people whose timeline for recovery (for those specific harms) happened to neatly concur with the six-month time frame of the commissions were included in the formal transitional justice process. The more complex and diverse experiences of both victimisation and recovery were not accommodated in this approach.

Nickson and Braithwaite (2013), building on insights from restorative justice, argue that there might be different points in time when victims or offenders are, emotionally, ready to deal with what has happened. In line with this idea, Crawford (2015: 481) posits that in principle, restorative justice is able to 'allow time and space to recognise and address the emotional dimensions of the harms that victims suffer'. Research has pointed out that participants in restorative justice have different opinions in regard to the best time to receive an offer to participate and might have different - overlapping and intersecting - needs at different times (Laxminarayan, 2014). In line with the diversity of experiences of harm and victimisation, the best time to initiate a restorative (or other) justice process will also differ among individuals, with certain actors, interventions or issues warranting a quicker or swifter approach, and others requiring a different pace or more protracted timeline. Restorative justice principles acknowledge these individual coping processes and are thereby well equipped to accommodate multiple timelines.

Therefore, the second dimension of our conceptual framework of transitional temporalities is that it should allow for the coexistence of multiple temporalities (in the sense of lived experiences) within and among various actors involved. It should acknowledge and visiblise these various temporalities and build on their strength, rather than ignoring them or seeking to mould them into one fixed 
temporal blueprint of unidirectional linear progress at a predetermined pace. This would accommodate the critique that transitional justice interventions currently do not adequately consider the various temporalities of compound and ongoing experiences of - harm or of individual versus institutional temporalities.

\subsection{Multidirectionality and temporal ecologies}

We have argued that if transitional justice wants to conceptualise temporality in a way that is more reflective of rights-holders' experiences, it can find inspiration in restorative justice principles, by accommodating the ongoingness and multilayeredness of timelines. Yet these two elements still assume linear progress, which is unlikely when working in a complex societal context. For example, violence often has a cyclical nature, and setbacks need to be factored in. Moreover, memory often does not work in a linear manner, which is particularly relevant in a context of individual and societal trauma (Caruth, 1996; Edkins, 2003; Harvey, 1996; Rothberg, 2009). Furthermore, vernacular understandings of time often do not easily let themselves be moulded into transitional justice's linear progressive calendar time (Hinton, 2018). We therefore need to complement the two preceding elements with a proposal that acknowledges nonlinearity, setbacks and absence of progress, in order to fully reflect the complexity and messiness of transitional temporalities. We refer to this non-linearity as multidirectionality. Here, too, restorative justice can offer inspiration.

Building on insights from restorative justice, Crawford (2015: 482) states that traumatic memories often 'free-float in time', necessitating a 'process of resituating and re-embedding that which resists temporalisation'. This view is in line with memory studies, more generally, which characterise memory as multidirectional and constructed through a process of ongoing negotiation, crossreferencing and borrowing. The concept of multidirectional memory recognises the heterogeneity of memories and experiences that make up the present (Rothberg, 2009: 3). Related to this multidirectional nature of memories is a current within the field of restorative justice that seeks to understand harm from an ecological perspective. This notion is grounded in the idea that social phenomena are constructed and influenced by multiple, multidirectional dynamically interacting influences (Bolívar, 2019; Harvey, 1996). The way in which an individual responds to a traumatic event is determined by a complex interaction of the individual, their environment and the traumatic event, and there is no linearity, predictability or teleological end point to this (Harvey, 1996). By recognising the social, cultural and political context of victimisation, an ecological perspective sheds light on the variety of outcomes of victimisation, including positive ones such as resilience and post-traumatic growth (Bolivar, 2012, 2019; Harvey, 1996). Victimisation can thus have a variety of effects, which tend to follow a discontinuous and non-linear pathway (Hayes, Laurenceau, Feldman, Strauss \& Cardaciotto, 2007: 721). If memory is multidirectional, traumatic memory free-floating in time, and the response to lived experiences of harm is multidetermined by dynamically interacting factors, this also involves non-linearity, setbacks and even cyclical temporal dynamics. An ecological perspective can take these factors into account. Grounding itself in lived realities, 
it allows for more contestation, across various levels (micro-, meso- and macro-) and in various directions (Bolívar, 2019; Cohen, 2016). Also in regard to the conceptualisation of memory as multidirectional (see Rothberg, 2009: 3) and as an 'ongoing negotiation', principles of restorative justice offer an inspiration. The acknowledgment that processes are 'dynamic, moving forwards and backwards in space and time', and the attention to rhythm and flow (Rossner, 2011: 116), allow for more circularity, potential setbacks and a multiplicity of experiences. This also relates to the non-linearity and contorted nature of the narratives of those who interact with justice (Mazzucato, 2018). Not only is the process of restorative justice dynamic and multidirectional, but also the way in which victims interact with it can be understood that way. Restorative justice has no predetermined outcome or measure of success and restoration, is shaped in itself through complex interaction and means different things to different individuals (Bolívar, 2012, 2019).

Also in the Chilean case, this ecological perspective brings to the fore temporal dynamics that would otherwise go unnoticed. The complex operations of memory, as well as the extent to which (ongoing) victimisation can have a variety of effects that follow a discontinuous and non-linear pathway became clear during the protests that began in 2019, when the past penetrated the present in multiple and unexpected ways. Not only can the protests themselves be understood as a reaction to ongoing violence and victimisation, the protest repertoire and rhetoric are also relevant. These featured multiple and unexpected references to the (memories of) past violence and agency and created an impression of the past forcefully penetrating the present. This was mirrored, for example, in Victor Jara's song El derecho de vivir en paz (1971) resonating on the streets in October $2019^{22}$ and the image and words of Salvador Allende ${ }^{23}$ being used in the mobilisation around a plebiscite on constitutional reform in October 2020. ${ }^{24}$ Earlier on, in 1999, Alexander Wilde (475) had referred to a similar phenomenon in the Chilean context as 'irruptions of memory', which he discussed as public events that break in upon Chile's national consciousness, unbidden and often suddenly, to evoke associations with symbols, figures, causes,

22 Victor Jara was a famous Chilean folk singer who was killed during the first few days of the dictatorship. His song El derecho de vivir en paz (translation: 'The right to live in peace') became an important symbol of resistance and was sung by a multitude of people during the protests of 2019: (www.youtube.com/watch?v=V_xRSfjCyrg). It was also used as a campaign slogan in the run-up to the plebiscite on constitutional reform in October 2020 by a group from the political right, opposing constitutional reform 'to live in peace'. This led to unrest and critique from the left-wing political community.

23 Sometimes in the form of direct reference, by linking the constitutional reform process to the words of Allende during his last speech: 'de nuevo se abrirán las grandes alamedas por donde pase el hombre libre para construir una sociedad mejor' (translation: 'the great avenues through which the free man passes will be opened again to build a better society') (https://elsiglo.cl/2020/08/27/ proceso-constituyente-abriendo-las-grandes-alamedas/).

24 This plebiscite on the modification of the Chilean Constitution was organised in an attempt to meet the demands of the 2019 protest movement. The Constitution established under military rule in 1980 is believed, by many, to hold in place structures of inequality and injustice and is often called the 'Pinochet constitution'. 
ways of life which to an unusual degree are associated with a political past that is still present in the lived experience of a major part of the population.

On 11 September 2020 the cyclical capacity of memory was further activated when the Museum of Memory and Human Rights broadcasted, 47 years after the coup d'état, radio transmissions of the day of the coup in real time through various online sources. During their 'month of memory' in September 2020, the Museum organised a wide range of activities, actively stimulating engagement with memories and pushing for their presence in the present. ${ }^{25}$

\section{Concluding remarks}

This article begins with the observation that transitions are ongoing long-term processes and that even some of the most paradigmatic cases of 'finished' transitions might not be as 'finished' as generally assumed. The practice of transitional justice has been criticised for failing to recognise the longue durée of (structural) violence, the diverse paces and pathways of overcoming harm, the complex nature of victimisation, the multidirectionality of memory and vernacular temporalities. However, scholarship problematising these temporal assumptions of transitional justice has so far not resulted in a proposal for a more adequate temporal framework. In this article we sought to develop such a framework by drawing on the principles and values of - an ideal version of restorative justice.

We used the Chilean case to illustrate the consequences of the currently dominant temporal framework, as well as the relevance of a restorative justiceinspired temporal framework for transitional justice. A closer look at the temporal dynamics underlying the Chilean transition makes it clear that the transitional justice process has been grounded in institutional rather than victims' lived experiences and understandings of time. This has resulted, among other things, in truth commissions with limited mandates and a concrete sequencing of mechanisms with fixed time frames for action. As victims' active engagement in protests suggests, the formal transitional justice process has not sufficiently been able to meet the expectations, needs and lived realities of the victims of human rights violations, who continue to face ongoing harm, victimisation and structural and socio-economic injustice (Borzutzky, 2017; Ferrara, 2015). ${ }^{26}$ To facilitate an analysis of how this past and present harm are linked, and how transitional justice can relate to it, we proposed a temporal framework rooted in restorative justice that revolves around three elements.

Through the platform https://conectadosconlamemoria.cl, the Museum invites visitors to engage with several elements of memory online (while the Museum remained closed on account of Covid-19), including an online visit to the Museum, live streaming of conversations, activities for children, revising archives, series and films.

26 Without neglecting, however, a few important developments. The National Institute of Human Rights (INDH) is a state-funded, autonomous organisation that actively collects testimonies and works to investigate and prosecute cases of human rights violations right away, in particular, violations that took place during the protest movement of 2019. This indicates a shift away from the culture of impunity through immediate action for justice in the recent Chilean context. 
First, it foregrounds ongoingness, both in the sense of acknowledging the longue durée of (structural) violence and victimisation, as well as in terms of casting transitional justice processes as 'architectures of permanence'. Building on insights from the field of restorative justice, our temporal framework proposes an open-ended time frame. Conceptually acknowledging protracted temporalities has the practical implication of not prescribing predetermined beginnings or end points and allowing for initiatives that are not time bound and that could remain active permanently. Secondly, our proposal draws on restorative justice principles by recognising that violence and victimisation affect individuals differently and that therefore the timelines of needs and recovery will also be different, multiple and overlapping. A more adequate temporal framework should therefore acknowledge and account for diverse individual (or collective) pathways of overcoming harm by accommodating multiple and overlapping timelines of harm and recovery. In practice, this warrants against the sequencing logic that characterises many transitional justice interventions. Thirdly, our proposal for a new temporal framework pays attention to multidirectionality and the possibility of non-linearity. A temporal framework that allows for circularity, multidirectionality, non-progress and potential setbacks is more responsive to the multiplicity of experiences of victims and society.

Applying this temporal framework to the Chilean case illustrates the importance of a better understanding of the complex temporal reality of the Chilean transition. While our proposal is conceptual, the Chilean case illustrates what this proposal could look like in practice. Yet there is more empirical work to be done in terms of examining in depth how this proposal plays out on the ground, and how empirical studies, also beyond the Chilean case, might fine-tune or complement certain dimensions of our proposal. What we found is that, even in paradigmatic cases of transitional justice like Chile, the existing temporal framework of transitional justice is not functioning optimally. This raises the question of how much more problematic these temporal assumptions may be in some of the aparadigmatic cases where transitional justice is increasingly employed, e.g. in dealing with ongoing conflict and violence (such as in Syria or the DRC), in dealing with historical and colonial harm (e.g. in Canada or Australia), or in navigating ambiguous transitions (such as Afghanistan or Colombia). In these cases, questions about temporal ongoingness, multilayeredness and multidirectionality are even more pressing, and we encourage further empirical explorations in this direction. The current analysis and future empirical explorations can further challenge current temporal working hypotheses of transitional justice and could potentially inspire interventions to become more multilayered and multidirectional, in order to be more responsive to victims' experiences, realities and vernacular understandings of time. In addition, this could stimulate restorative justice theory and practice to further develop, especially in cases with increased societal complexity (such as terrorism, environmental crimes or child sexual abuse). We argue that a conceptual framework that approaches transitional temporalities in this way has the advantage of bringing to the fore several dynamics that would otherwise go unnoticed and that, in practice, have often gone unnoticed. 


\section{References}

Adam, B. (2004). Time. Cambridge: Polity Press.

Adam, B. (2008). Of timescapes, futurescapes and timeprints [Presentation at Lüneburg University]. Retrieved from http://citeseerx.ist.psu.edu/viewdoc/summary? doi=10.1.1.594.1289 (last accessed 24 February 2021).

Aldana, R. (2006). A victim-centered reflection on truth commissions and prosecutions as a response to mass atrocities. Journal of Human Rights, 5(1), 107-126. doi: $10.1080 / 14754830500485916$.

Andrieu, K. (2016). Confronting the dictatorial past in Tunisia: human rights and the politics of victimhood in transitional justice discourses since 2011. Human Rights Quarterly, 38(2), 261-293. doi: 10.1353/hrq.2016.0028.

Arthur, P. (2009). How "transitions" reshaped human rights: a conceptual history of transitional justice. Human Rights Quarterly, 31(2), 321-367. doi: 10.1353/hrq.0.0069.

Aste Leiva, B. (2020). Estallido social en Chile: la persistencia de la constitución neoliberal como problema. Diritto Pubblico Comparato ed Europeo, 1, 3-19.

Bazemore, G. \& Walgrave, L. (1999). Restorative juvenile justice: in search of fundamentals and an outline for systemic reform. In G. Bazemore \& L. Walgrave (eds.), Restorative juvenile justice: repairing the harm of youth crime (pp. 45-74). Monsey: Criminal Justice Press.

Bell, C. (2009). Transitional justice, interdisciplinarity and the state of the 'field' or 'nonfield.' International Journal of Transitional Justice, 1, 5-27. doi: 10.1093/ijtj/ijn044.

Bolívar, D. (2012). Victim-offender mediation and victim's restoration: a victimological study in the context of restorative justice ( $\mathrm{PhD}$ Dissertation). Leuven: Catholic University of Leuven.

Bolívar, D. (2019). Restoring harm. A psychosocial approach to victims and restorative justice. London: Routledge.

Borzutzky, S. (2017). Human rights policies in Chile. The unfinished struggle for truth and justice. Cham: Springer International Publishing AG.

Braithwaite, J. (2003). Principles of restorative justice. In A. von Hirsh, J. Roberts \& A. Bottoms (eds.), Restorative justice and criminal justice. Competing or reconcilable paradigms? (pp. 1-21). Portland: Hart Publishing.

Braithwaite, J. (2016). Learning to scale up restorative justice. In K. Clamp (ed.), Restorative justice in transitional settings (pp. 173-189). New York: Routledge.

Caruth, C. (1996). Unclaimed experience: trauma, narrative and history. London: Johns Hopkins University Press.

Castillejo-Cuéllar, A. (2014). Historical injuries, temporality and the law: articulations of a violent past in two transitional scenarios. Law Critique, 25(1), 47-66. doi: 10.1007/ S10978-013-9127-Z.

Clamp, K. (2019). Transforming restorative justice for transitional settings. In M. Natarajan (ed.), International and transnational crime and justice (pp. 456-460). Cambridge: Cambridge University Press.

Clamp, K. \& Doak, J. (2012). More than words: restorative justice concepts in transitional justice settings. International Criminal Law Review, 12, 339-360. doi: $10.1163 / 157181212 \times 648824$.

Cohen, R. (2016). Restorative justice. In C. Sabbagh \& M. Schmitt (eds.), Handbook of social justice theory and research (pp. 257-274). New York: Springer.

Collins, C. (2013). Chile a más de dos décadas de justicia de transición. Revista Política, 51(2), 79-113. 
Comisión asesora para la calificación de detenidos desaparecidos, ejecutados y víctimas de prisión política y la tortura (2010). Informe de la comisión presidencial asesora para la calificación de detenidos desaparecidos, ejecutados políticos y víctimas de prisión política $y$ tortura. Retrieved from https://notascect.files.wordpress.com/2011/08/ informe2011.pdf (last accessed 24 February 2021).

Comisión nacional sobre prisión política y tortura (2004). Informe de la comisión nacional sobre prisión politica y tortura (Valech). Retrieved from www.derechoshumanos.net/ paises/America/derechos-humanos-Chile/informes-comisiones/Informe-ComisionValech.pdf (last accessed 24 February 2021).

Crawford, A. (2015). Temporality in restorative justice: on time, timing and timeconsciousness. Theoretical Criminology, 19(4), 470-490. doi: $10.1177 / 1362480615575804$.

Daly, K. (2006). The limits of restorative justice. In D. Sullivan \& L. Tifft (eds.), Handbook of restorative justice: a global perspective (pp. 134-146). New York: Routledge.

Daly, K. (2015). What is restorative justice? Fresh answers to a vexed question. Victims and Offenders, 11, 9-29. doi: 10.1080/15564886.2015.1107797.

De Keijser, J.W. (2000). Punishment and purpose. From moral theory to punishment in action. Amsterdam: Thela Thesis.

Demiragic, A. \& Hodzic, E. (2013). The bleak visions of literary justice for survivors of Srebrenica: examining the fictional narratives of Srebrenica genocide in light of the insights from transitional justice. In P. Rush \& O. Simic (eds.), The arts of transitional justice. culture, activism, and memory after atrocity (pp. 135-154). New York: Springer.

Edkins, J. (2003). Trauma and the memory of politics. Cambridge: Cambridge University Press.

Eriksson, A. (2009). A bottom-up approach to transformative justice in Northern Ireland. The International Journal of Transitional Justice, 3, 301-320. doi: 10.1093/ijtj/ijp019.

Ferrara, A. (2015). Assessing the long-term impact of truth commissions. The Chilean truth and reconciliation commission in historical perspective. London: Routledge.

Fletcher, L. \& Weinstein, H. (2017). Transitional justice and the 'plight' of victimhood. In C. Lawther, L. Moffett \& D. Jacobs (eds.), Research handbook on transitional justice (pp. 244-266). Cheltenham: Edward Elgar Publishing.

Frederiksen, E. (2008). Reconstituting political community: truth commissions, restorative justice and the challenges of democratic transition. Paper presented at the meeting of the Canadian Political Science Association, Vancouver, Canada. Retrieved from http:// citeseerx.ist.psu.edu/viewdoc/download?doi=10.1.1.552.1787\&rep=rep1\&type=pdf (last accessed 24 February 2021).

Galtung, J. (1969). Violence, peace and peace research. Journal of Peace Research, 6(3), 167-191.

Galtung, J. (1990). Cultural violence. Journal of Peace Research, 27(3), 291-305. doi: $10.1177 / 0022343390027003005$.

Gómez-Barris, M. (2015). Mapuche mnemonics: beyond modernity's violence. Memory Studies, 8(1), 75-85. doi: 10.1177/1750698014552410.

Gready, P. \& Robins, S. (2014). From transitional to transformative justice. International Journal of Transitional Justice, 8(3), 339-361.

Goodale, M. (2006). Ethical theory as social practice. American Anthropologist, 108(1), 25-37.

Harvey, M. (1996). An ecological view of psychological trauma and trauma recovery. Journal of Traumatic Stress, 9(1), 3-23. doi: 10.1007/BF02116830.

Hayes, A., Laurenceau, J., Feldman, G., Strauss, J. \& Cardaciotto, L. (2007). Change is not always linear: the study of nonlinear and discontinuous patterns of change in 
psychotherapy. Clinical Psychology Review, 27, 715-723. doi: 10.1016/j.cpr. 2007.01.008.

Hayner, P. (2011). Unspeakable truths. Transitional justice and the challenge of truth commissions (2nd ed.). New York: Routledge.

Hickey, S. \& Mohan, G. (2004). Participation: from tyranny to transformation? London: Zed Books.

Hinton, A.L. (2018). Justice, temporality and shame at the Khmer Rouge Tribunal. In L. Hinton \& H. Willemsen (eds.), Temporality and shame. Perspectives from psychoanalysis and philosophy (pp. 186-213). New York: Routledge.

Homer-Dixon, T. (2011). Complexity science. Oxford Leadership Journal, 2(1), 1-15.

Hristova, M., Ferrándiz, F. \& Vollmeyer, J. (2020). Memory worlds: reframing time and the past-an introduction. Memory Studies, 13(5), 777-791. doi: $10.1177 / 1750698020944601$.

Huyssen, A. (2000). Present pasts: media, politics, amnesia. Public culture, 12(1), 21-38.

Ignatieff, M. (1996). Articles of faith. Index of Censorship, 25(5), 110-122. doi: 10.1177/030642209602500522.

Ketelaars, E. (2018). Gendering Tunisia's transition: transformative gender justice outcomes in times of transitional justice turmoil? International Journal of Transitional Justice, 12, 407-426. doi: 10.1093/ijtj/ijy016 .

LaCapra, D. (2001). Writing history, writing trauma. Baltimore: Johns Hopkins University Press.

Lambourne, W. \& Niyonzima, D. (2016). Breaking cycles of trauma and violence: psychosocial approaches to healing and reconciliation in Burundi. In P. GobodoMadikizela (ed.), Breaking intergenerational cycles of repetition: a global dialogue on historical trauma and memory (pp. 291-307). Opladen: Barbara Budrich Publishers.

Laub, D. (1995). Truth and testimony: the process and the struggle. In C. Caruth (ed.), Trauma: explorations in memory (pp. 61-75). Baltimore: Johns Hopkins University Press.

Laxminarayan, M. (2014). Accessibility and initiation of restorative justice. Leuven: European Forum for Restorative Justice.

Leebaw, B. (2001). Restorative justice for political transitions: lessons from the South African Truth and Reconciliation Commission. Contemporary Justice Review, 4(3-4), 267-289.

Lin, O. (2005). Demythologizing restorative justice: South Africa's Truth and Reconciliation Commission and Rwanda's Gacaca courts in context. ILSA Journal of International \& Comparative Law, 12(4), 41-86.

Macdonald, A. (2015). From the ground up: what does the evidence tell us about local experiences of transitional justice. Transitional Justice Review, 1(3), 72-121. doi: 10.5206/tjr.2015.1.3.4.

Madlingozi, T. (2010). On transitional justice entrepreneurs and the production of victims. Journal of Human Rights Practice, 2(2), 208-228. doi: 10.1093/jhuman/huq005.

Marshall, T.F. (1996). The evolution of restorative justice in Britain. European Journal on Criminal Policy and Research, 4, 21-43. doi: 10.1007/BF02736712.

Mazzucato, C. (2018, June 14-16). Reconciling straight lines with circles? Towards an alliance between (criminal) law and (restorative) justice [Keynote Presentation]. 10th International Conference of the European Forum for Restorative Justice, Tirana, Albania. Retrieved from www.euforumrj.org/sites/default/files/2019-11/finalbooklet-merged-online1.pdf (last accessed 24 February 2021). 
McAuliffe, P. (2014). Ariel Dofman's Death and the Maiden as a mirror reflecting the dilemmas of transitional justice policy. In P. Rush \& O. Simić (eds.), The arts of transitional justice (pp. 81-98). New York: Editorial Springer.

McEvoy, K. \& Eriksson, A. (2006). Restorative justice in transition. Ownership, leadership and 'bottom-up' human rights. In D. Sullivan \& L. Tifft (eds.), Handbook of restorative justice. A global perspective (pp. 321-336). London: Routledge.

McLeod, L., Dimitrijevic, J. \& Rakocevic, B. (2013). Artistic activism, public debate and temporal complexities: fighting for transitional justice in Serbia. In P. Rush \& O. Simic (eds.), The arts of transitional justice. Culture, activism, and memory after atrocity (pp. 25-42). New York: Springer.

Miller, Z. (2008). Effects of invisibility. International Journal of Transitional Justice, 17(2), 266-291. doi: 10.1093/ijtj/ijn022.

Minow, M. (1998). Between vengeance and forgiveness: facing history after genocide and mass violence. Boston: Beacon Press.

Morris, A. (2002). Critiquing the critics: a brief response to critics of restorative justice. British Journal of Criminology, 42, 596-615. doi: 10.1093/bjc/42.3.596.

Moyano, C. (2019). Intelectuales y el "tiempo histórico de la Transición": reflexiones a propósito de la coyuntura contemporánea. Contribuciones científicas y tecnologicas, 44(1), 11-17.

Mueller-Hirth, N. (2016). Temporalities of victimhood: time in the study of postconflict societies. Sociological Forum, 32(1), 1-21. doi: 10.1111/socf.12323.

Nickson, R. \& Braithwaite, J. (2013). Deeper, broader, longer transitional justice. European Journal of Criminology, 11(4), 445-463. doi: 10.1177/1477370813505954.

Nora, P. (1989). Between memory and history: Les lieux de mémoire. Representations, 26, 7-24. doi: $10.2307 / 2928520$.

Nowotny, H. (2017). An orderly mess. New York: Central European University Press.

Obel Hansen, T. (2017). The time and place of transitional justice. In C. Lawther, L. Moffett \& D. Jacobs (eds.), Research handbook on transitional justice (pp. 34-51). Cheltenham: Edward Elgar Publishing.

O'Connell, J. (2005). Gambling with the psyche: does prosecuting human rights violators console their victims. Harvard International Law Journal, 46(2), 295-346.

O’Mahony, D., Doak, J. \& Clamp, K. (2012). Restorative justice and transitional justice in post-conflict societies: youth justice reforms in Northern Ireland and South Africa. The Northern Ireland Legal Quarterly, 63(2), 269-290.

Oteíza, T. \& Pineur, C. (2010). La temporalidad, recurso estratégico en documentos oficiales de derechos humanos en Chile. Estudios Filológicos, 46, 81-99.

Raehme, S. (2018). Frictions in transitional justice processes: Colombia's victims law, integral reparation and the temporality of multiple victimization in displaced women. Gobernar: The Journal of Latin American Public Policy and Governance, 2(1), 33-56. doi: 10.22191/gobernar/vol2/iss1/3.

Rebolledo, O. \& Rondón, L. (2010). Reflexiones y aproximaciones al trabajo psicosocial con víctimas individuales y colectivas en el marco del proceso de reparación. Revista de Estudios Sociales, 36, 40-50.

Robins, S. (2011). Towards victim-centred transitional justice: understanding the needs of families of the disappeared in postconflict Nepal. International Journal of Transitional Justice, 5(1), 75-98. doi: 10.1093/ijtj/ijq027.

Robins, S. (2017). Failing victims? The limits of transitional justice in addressing the needs of victims of violations. Human Rights and International Legal Discourse, 1, 41-58.

Roht-Arriaza, N. \& Mariezcurrena, J. (eds.). (2006). Transitional justice in the twenty-first century. Beyond truth versus justice. Cambridge: Cambridge University Press. 
Rossner, M. (2011). Emotions and interaction ritual. A micro analysis of restorative justice. British Journal of Criminology, 51, 95-119. doi: 10.1093/bjc/azq075.

Rothberg, M. (2009). Multidirectional memory: remembering the holocaust in the age of decolonization. Stanford: Stanford University Press.

Schmid, E. (2015). Taking economic, social and cultural rights seriously in international criminal law. Cambridge: Cambridge University Press.

Sodaro, A. (2018). Exhibiting atrocity. Memorial museums and the politics of past violence. London: Rutgers University Press.

Shapland, J., Atkinson, A., Atkinson, H., Colledge, E., Dignan, J., Howes, M., Johnstone, J., Robinson, G. \& Sorsby, A. (2006). Situating restorative justice within criminal justice. Theoretical Criminology, 10(4), 505-532. doi: 10.1177/1362480606068876.

Spiegel, G. (2002). Memory and history. Liturgical time and historical time. History and Theory, 41(2), 149-162. doi: 10.1111/0018-2656.00196.

Subsecretaría de Derechos Humanos (2017). Primer plan nacional de derechos humanos. Retrieved from https://planderechoshumanos.gob.cl/files/plan.pdf (last accessed 24 February 2021).

Terdiman, R. (1993). Present past: modernity and the memory crisis. New York: Cornell University Press.

Teitel, R. (2000). Transitional justice. New York: Oxford University Press.

Turner, C. (2017). Transitional justice and critique. In C. Lawther, L. Moffett \& D. Jacobs (eds.), Research handbook on transitional justice (pp. 52-73). Cheltenham: Edward Elgar Publishing.

UDP (2019). Informe anual sobre derechos humanos en Chile 2019. Retrieved from https://derechoshumanos.udp.cl/informe-anual/informe-anual-sobre-derechoshumanos-en-chile-2019-2/ (last accessed 24 February 2021).

Vazquez, R. (2011). Translation as erasure: thoughts on modernity's epistemic violence. Journal of Historical Sociology, 24(1), 27-44. doi: 10.1111/j.1467-6443.2011.01387.x.

Walgrave, L. (2008). Restorative justice, self-interest and responsible citizenship. Cullompton: Willan Publishing.

Weitekamp, E., Vanspauwen, K., Parmentier, S., Valiñas, M. \& Gerits, R. (2006). How to deal with mass victimization and gross human rights violations. A restorative justice approach. In U. Ewald \& K. Turković (eds.), Large scale victimisation as a potential source of terrorist activities (pp. 217-241). Amsterdam: IOS Press.

Wilde, A. (1999). Irruptions of memory: expressive politics in Chile's transition to democracy. Journal of Latin American Studies, 31(2), 473-500.

Yerushalmi, Y.H. (2002). Zakhor. Jewish history and Jewish memory. Seattle: University of Washington Press.

Zehr, H. (2002). The little book of restorative justice. Intercourse: Good Book.

Zunino, M. (2019). Justice framed: a genealogy of transitional justice. Cambridge: Cambridge University Press. 